\title{
Music Education and the Construction of Musical Knowledge in Spain and Brazil
}

\author{
Alberto Cabedo Mas, Universitat Jaume I, Castellón, Spain \\ Flávia Motoyama Narita, Universidade de Brasília, Brazil
}

\begin{abstract}
This paper is intended to discuss what counts as musical knowledge in the context of two countries: Spain and Brazil. In Spain, issues concerning cultural diversity in schooling have led us to investigate how both teachers and students conceive the value of different musics in educational contexts. In Brazil, the recent Law 11.769/2008 made music a compulsory subject in schools. Since then, there have been increasing discussions about which music(s) should be considered valid to be taught, and how it can be implemented in different levels of schooling. We are going to address these topics considering the idea that music education can help to shape, perpetuate, legitimate and modify ideologies concerning the value of music. Thus, we claim the importance of opening up musical curricula and incorporating different musics in schooling as a means to construct musical realities in these countries and deconstruct dominant ideologies concerning musical values and meanings. Such concepts will be analyzed according to Green's (1988) theory aiming to celebrate musical practices in order to readapt the function of music education to the social contexts these countries demand.
\end{abstract}

Keywords: Music, Education, Knowledge, Spain, Brazil

\section{Introduction}

$\mathrm{T}$

HIS PAPER IS a result of a discussion initiated in a seminar on the Sociology of Music Education attended by the authors, who come from Spain and Brazil. While Spain has been offering music as a compulsory subject, with specialized music teachers, in primary education since the beginning of 1990s, Brazil has only recently placed music back on its school curricula. The current realities of these countries are briefly dealt with as the authors suggest an agenda for music education in their countries, analyzing how musical knowledge has been constructed.

Addressing to Green's theories (1988; 1999; 2003a; 2003b) concerning the power of ideologies in validating and reproducing musical knowledge and practices, we will discuss how formal music education has constructed values about what is considered to be good educational musical practices in both contexts. The following section presents Green's ideas in a nutshell. Then, we pose curricular issues related to cultural diversity in Spain. Subsequently, some differences in the Brazilian music education scenario are dealt with and, finally, in the last section, we present some considerations for music education in our countries.

\section{Ideology and Formal Education}

Drawing on research about the uses of different types of music in formal education, particularly Western classical music and popular music, Green (2003b) posits that, although one could claim that the curriculum in many countries offers a diversity of music, the way each 
of them is approached and dealt with in classrooms reflects the value attributed to each type of music. In Britain, she found out that supporters of popular music theoretically tend to attribute its value to the qualities usually related to classical music-"universality, complexity, originality [and] autonomy"-but, in practice, they treat popular music as if it lacks such qualities (Green, 2003b: 266). Besides criticisms for using values that may not be pertinent to popular music, this approach affirms classical music ideology, as popular music is taught, analyzed and practiced according to classical music parameters such as notated scores. As a result, the experience of popular music in school may sound 'dissonant' to schooling (i.e. classical music) parameters. So, even if a curriculum offers equal opportunities for engaging with a variety of music, the pedagogical practices usually rely heavily on classical music ideology, conveying a clear message of what is considered appropriate to school settings and, consequently, what is considered a valid knowledge.

So, besides curricular changes, Green invites us to rethink our pedagogical strategies aiming at what she calls a celebratory musical experience, which is the result of affirmative responses to musical meanings when we get involved with music, listening to it, playing, improvising, composing etc. She acknowledges two different musical meanings that coexist in every musical experience: the inherent or intersonic (Green, 2008) meanings, and the delineated meanings. Both arise from our response to music; however, the former arises when both the sign and the object are made of musical materials; that is, the sound, a musical material we hear, is identified as other musical materials 'decoded' as notes, chords and phrases. The latter arises from our extra-musical associations brought by the musical materials; that is, the sound we hear brings us memories related to the various contexts of life. An affirmative response to both types of musical meanings occurs when we are used to a certain style of music and are able to understand the sound relationships within this style, and we also relate it to situations or sensations we identify with. This positive musical experience is what Green (1988: 137) calls celebration. She also explains that our responses to both types of musical meanings can lead us to alienated or ambiguous experiences. Alienation would be the negative response to both delineated and intersonic meanings, while ambiguity would be the result of a positive response to only one of those meanings.

Bearing this in mind, we could try to promote more musical practices that broaden pupils' familiarity with styles so that they are able to understand how sound materials function within each style. In Green's (2005: 33) research using informal learning practices, she found out that "when [pupils] engage with music's materials themselves, ... [they] are touching on an aspect of inherent meaning which is virtually freed for a moment from social context". This allows new delineations to come up and, consequently, change previous negative responses into positive experiences that lead to celebration.

\section{The Construction of a Musical Curriculum and Cultural Diversity in Spain}

We are aware that each educational proposal is based on some principles which need to be applied in one way or another depending on the frame of reference for the place where it is to be implemented. Every teaching organization, just like every individual involved in educational processes, must adapt its educational work to the particular social context where it is established. Music education should not be indifferent to this fact. It should therefore be 
designed starting with a critical reflection in order to develop a musical curriculum to meet the needs of each particular context and society.

Spain has historically been a multicultural nation and nowadays it is even more so. Cultural diversity has been a reality that Spanish society has often had to deal with, debate and organize in education. The tremendous development of the media, means of transport and technology have greatly helped to increase migration flows which, in the Spanish situation, have resulted in the growth of multiculturalism in our classrooms. We consider that cultural diversity clearly enriches educational forums. The existence of a multicultural reality offers a chance to increase our knowledge by learning from other cultures. It makes different organizational structures possible. It also extends knowledge and promotes learning from other viewpoints, helping us to discover other social and interpersonal ways of living together.

However, a multicultural situation involves several conflicts that need to be managed properly. The discovery of other cultures can be the origin of a violent relationship between people. This must necessarily be well articulated, so peaceful communication can guide our everyday coexistence in the classroom and go beyond the boundaries of the school. It is our responsibility to promote an attitude that is not merely based on respect and tolerance towards diverse cultural forms, but which also stimulates relationships based on recognition and interaction. Only in this way will we be able to achieve an actual intercultural relationship between people.

The promotion of an intercultural attitude is, therefore, a necessary competence in our educational system. The Organic Law 2/2006, dated 3rd May, of Education (2006: 17165), currently in force, spells out, as one of the essential aims of educational processes, "respect for and recognition of Spain's linguistic and cultural plurality and of inter-culturality as an enriching factor in society".

We uphold the idea that the music classroom can be used as a proper place to develop competences focused on promoting intercultural ways of living together and of learning from our differences. This is firstly because we understand that the educational process is capable of modifying the social reality that surrounds us. Teachers must have the abilities and tools to encourage a change in relationships in their surroundings. Secondly, we highlight the music classroom as a propitious environment for learning how to coexist due to music's capacity to belong not only to the aesthetic dimension of people, but also to their cultural and communicative dimensions.

The main proposals for dealing with the incorporation of the intercultural competence in the music classroom include, firstly, the broadening of musical styles in the educative curricula. Historically, there has been a tendency to reduce the musical styles in the school curriculum. Because of this, few musical styles have been considered appropriate for the classroom. Western classical music has been the paradigm of this dominant ideology that has constructed musical knowledge in recent centuries in Spain. However, new views taken from music education theory have, over the last 40 years, proposed the inclusion and validation of other musics in the educational environment.

The deconstruction of this dominant ideology in music education has allowed us to introduce competences focused on developing intercultural skills in the music classroom. The need to introduce a plurality of musical styles and genres is upheld by a series of benefits that this provides to the student at both social and musical levels.

From a social point of view, the study of cultural diversity through music entails the construction of intercultural awareness. It also promotes tolerance and mutual understanding, 
and contributes to the elimination of both racial and generational prejudices (Giráldez, 1998). One of the important points of intercultural educational theories is based on knowledge of one's own and other people's cultures. By understanding music as an element that belongs to the cultural dimension of societies, we can discover similar and different features between cultural organizations through their music. This knowledge is essential to promoting an intercultural attitude (Siankope and Villa, 2004: 16).

From a musical view, learning different musical styles contributes to numerous benefits in the development of musical abilities. Musical plurality in the curriculum encourages the acquisition of listening and performing skills in certain musical styles, which other styles lack. It also promotes musical critical thinking and a breadth of views in analyzing different kinds of music; reinforces the knowledge of musical elements, and develops motor abilities. Increasing the understanding of diverse musical materials will provide the student with greater tolerance to new or strange musical styles (Giráldez, 1998). The exclusive use of only one type of music in education limits, therefore, the range of possibilities offered by musical activity and reduces the acquisition of musical abilities.

By combining the social and musical benefits of plural music education, we reflect the need to incorporate an intercultural dimension in the music classroom. In our opinion, music education in Spain has made some advances in opening up the curriculum as is required in education. However, we believe it has not yet taken a decisive step: it has not made the necessary efforts to manage all these different cultural and musical situations in music classrooms.

The first time that the inclusion of other musics on the music education curriculum was debated was in 1966 (Giráldez, 1998). The new multi-cultural music education began to be developed in the '70s, mainly in the UK and the USA. In Spain, this proposal did not become important until the '90s, with the educational reform of the LOGSE (General Organic Ed ucation System Law, 1990). However, this inclusion focused mainly on traditional folk music from the Autonomous Communities (Ibarretxe Txakartegi and Díaz Gómez, 2008: 343344). Since then, several documents encouraging multi-cultural music education in Spain have been written. Important musicologists and musical educators, like Giráldez, Diaz Gómez, Ibarretxe or Martí have devoted research to the study, promotion and implementation of intercultural music educational practices. In 1997, the journal Euphony dedicated one volume to intercultural music education, and the Ministry of Education and Science supported the publishing in 2003 of a series of Intercultural Education Workbooks, including the book Music and Interculturalism, written by Siankope and Villa. Beyond folk music, other modern popular music styles, such as jazz, rock, hip-hop, heavy or Top 40 have been included in the music classroom. Finally, in addition to learning other musical styles, some schools have promoted knowledge of other societies and their cultural profiles through their music.

Nevertheless, these musical practices are frequently relegated to mere one-off or isolated activities. Although the inclusion of diverse musical styles in the classroom is sometimes supported, Western classical music is often still considered as the best for educational purposes. Furthermore, Spanish teachers tend to include different musical styles in the music classroom using the educational criteria of Western music. Because of this, they often feel unable to teach other musics using classical practices and guidelines. Therefore, as Green noticed in UK, also in the Spanish context "rather than intramusical processes (the "notes"), teachers tend to concentrate on extramusical associations related to the social circumstances of the music's production and reception, such as the social functions or effects of the music, 
the dress of the performers, or the lyrics" (2003b: 266). This therefore reinforces the reproduction and legitimization of a previously constructed ideology about the value of certain musics depending on their educational properties. So, in the end, the constant process of validation of what counts as good music on the Spanish music education scene continues.

We tend to think that, mostly, the exclusion of certain musics from music education is not a consequence of not being valued by the music teacher himself or herself. Music teachers are often aware of the need to broaden their students' and their own musical scopes. However, they limit the time devoted to teaching styles of music they feel unfamiliar with-music that does not form part of their own musical background-because their lack of knowledge makes them feel uncomfortable (Giráldez, 1998).

We are fully convinced that now, when interculturalism is constantly being debated on the international scene, we, as music teachers, should rethink this issue and try to develop new music education practices and proposals concerning cultural diversity. Only by collecting and analyzing multiple and different views will music teachers be able to offer some common directives in order to promote the construction of a plural and creative music education. Such an education must also include and be adapted to the complexity of the society in which it is established. We understand that only then can the music classroom become a space that, beyond music learning, promotes intercultural relationships among its members, promoting peaceful coexistence between people.

\section{Music Education in Brazil: Towards the Implementation of a New Law}

Having discussed the inclusion of cultural diversity on the curriculum in Spain, we will now present some issues related to the implementation of a music curriculum in Brazil, since the Law 11.769 was signed in 2008.

In Brazil, we are now living a moment in which we are going to witness what is going to happen to musical practices. They are found in conservatories, non-governmental organizations (NGOs), private schools and other settings such as churches and educational/cultural projects sites and are carried out both in groups and on one-to-one tuition basis. Every musical practice has been conducted depending on the teacher's/ leader's/ master's/ facilitator's beliefs about what counts as valid musical knowledge and skills. In formal and non-formal settings, it is mostly Western classical music ideology that has been validated, as Arroyo (2001) pointed out when she investigated Popular Music in a conservatoire in Uberlândia, a city in the state of Minas Gerais, Southeast Brazil. Ten years have passed, and some practices have changed, but the power of classical music ideology can be found in discourses in the academic world, the places responsible for music training. As Luedy (2009) reports in a discussion about the need for musical literacy (reading and writing Western musical notation) as a pre-requisite for entering an undergraduate music course, we can infer the value attributed to notational skills to the detriment of music making. Without judging whether this value attribution is right or wrong, the fact is that such a decision may be taken as a model for shaping other music teaching practices and choices that will now, formally, happen below undergraduate level, in the entire compulsory schooling system in Brazil, according to the Law 11.769/2008.

After this Law was signed, in August 2008, discussions about what music should be taught, how it should be done and who should teach it in schools have increasingly been addressed. Inequalities of access to music education before the above-mentioned law, as in many regions 
it was restricted to those who could afford private tuition or conservatories, may have led to an uneven distribution and concentration of music teachers in some areas in Brazil to the benefit of wealthy regions. However, as Figueiredo (2000) has shown, the political collaboration between universities and Education Offices has proven effective in the design of a curriculum and implementing music teaching practices that cater for local needs and for a diversity of musical values and beliefs. So, long before the new law made music a compulsory subject in schools, Florianópolis, in the state of Santa Catarina, South Brazil, has been providing music lessons for its pupils.

Unfortunately, this is not the situation in many other places in Brazil. At the eleventh hour of the 3-year deadline given for schools to adapt to the new law, one of the main concerns is the lack of music teachers in certain areas of the country and the consequences that a "provisional" remedy for this may cause: the employment of teachers without musical training. In a recent Internet discussion forum, a music teacher from Rio Grande do Norte, a state in Northeast Brazil, explained his worries about teachers from other fields of knowledge being trained to teach music due to the lack of music teachers. As a response to his post, a colleague from the state of Ceará, also Northeast Brazil, posits that in his state, although the teachers who will attend in-service training may be from other fields of knowledge, they will need to prove their knowledge of music and teaching skills in a mock lesson. He adds that the in-service training will be delivered in partnership with the Music Department of the Universidade Federal do Ceará, a government-funded university.

Initial teacher training in Brazil is also a responsibility of universities and other Higher Education institutions. They have been adapting their curricula since the Resolution no.1 was issued in 2002 by the National Council for Education presenting the guidance for General Initial Teacher Education courses. Based on such Resolution, institutions of Higher Education with music degrees started shaping their curricula aiming to train prospective music teachers to work at different levels of schooling. However, it seems that the 72 institutions ${ }^{1}$ that offer music teacher education in Brazil are not enough to cover the need for teachers once the law is in operation.

As can be seen, the Law 11.769/2008 has unfolded issues related to music teacher training, which is formally under the responsibility of universities and colleges. Such institutions are being compelled to join efforts with other organizations to offer teacher training to help meet the demand for music teachers. The Ministry of Culture and its associate organizations have already shown willingness to cooperate in this process, as Lemos (2010: 118) presents the support from Funarte, the National Foundation for the Arts, in gathering representatives from different areas connected to music-musicians, music teachers, universities, Education Offices, the Brazilian Society for Music Education (ABEM), music schools among others-to draw up a strategic plan to implement music lessons according to the new law. The discussions include flexibility in initial music teacher training via a mixed-mode course, in-service training for those without formal musical training and partnerships with music schools and social projects related to music. While on one hand the need for music teachers in Brazilian schools is undeniable in order to implement the law, on the other hand, it is fundamental to consider the quality of the lessons if we want music to be enjoyed to its full potential. The aforementioned strategies need to be carefully planned and the formal institutions responsible

\footnotetext{
${ }^{1}$ Data drawn from research conducted by Mateiro (2009).
} 
for music teacher training need to get involved in collaborative work between the different sectors related to music.

Besides such partnerships, higher education institutions are being compelled to increase their range of courses via distance learning and evening classes. Although some new lecturers are being hired and, in the case of government-funded institutions, public contests carried out to hire academics, the work overload is a concern if we want to guarantee the quality of the teacher training delivered. Thus, not only are music teachers needed in primary and secondary schools, but they are also needed in HE institutions in order to provide teacher training and carry out research related to the many musical practices still available in our diverse country.

The implementation of the Law $11.769 / 2008$ will certainly need to be complemented by other government actions. In addition to strategies for hiring more academics in HE institutions and more teachers in primary and secondary schools, there is an urgent need for policies to help schools adapt a place for musical practices and to obtain musical instruments and other equipment to enhance the quality of music lessons. As further efforts, we could highlight actions taken by the state of Paraná, South Brazil, whose Education Office provided musical instruments to schools and, since 2003, has organized three public contests to hire teachers. The Brazilian Society for Music Education (ABEM) has also been actively engaged in public policies, dialoguing with governments and promoting discussions among music teachers through regional and national annual conferences. As can be seen, there is still much to be done to ensure that musical practices will in fact be part of the whole Brazilian compulsory schooling system. The passing of the law was the first step and we must now be willing to seek different strategies for implementing musical practices in schools, respecting the diversity of musics and practices that have been implemented informally and being aware of the power formal education has to affirm whatever ideologies it subscribes to.

\section{Final Considerations}

As we have been attempting to show, we uphold the approach that, through broadening the musical styles on music education curricula, and by also incorporating new music pedagogies, such as bringing informal music learning practices into the music classroom (Green, 2008), students will have wider experience with music that may lead to celebratory practices and a better understanding of musical knowledge. However, learning from different cultures, other sub-cultures and diverse social classes may require different pedagogical approaches that teachers need to be at least open to embrace. The music teacher education offered by the HE institutions therefore needs to be attuned to this demand of a globalized/localized world and we, as music teachers and as music teacher trainers, need to be fully aware of the ideology we are subscribing to in each choice we make. Whether we are perpetuating, challenging or changing ideologies, what is fundamental is that we should remain aware of the power everyone has when exercising their choices. So, if we want to offer our students celebratory musical practices, we really need to value and allow room for different musics and musical practices. 


\section{References}

Arroyo, Margarete (2001), "Música Popular em um conservatório de Música”, Revista da ABEM, Porto Alegre, 6, 59-67.

ABEM-Associação Brasileira de Educação Musical http://www.abemeducacaomusical.org.br/ Brasil (2008), Presidência da República, Casa Civil, Subchefia para Assuntos Jurídicos, Lei no 11.769 de 18 de agosto de 2008. Altera a Lei no 9394, de 20 de dezembro de 1996, Lei de Diretrizes e Bases da Educação, para dispor sobre a obrigatoriedade do ensino da música na educação básica. http://www.planalto.gov.br/ccivil_03/_Ato2007-2010/2008/Lei/L11769.htm Retrieved April 29, 2011.

Discussion Forum http://groups.google.com/group/professoresdemusicadobrasil/browse_thread/ thread/603392e4f70d9424

Figueiredo, Sergio (2000), "Proposta curricular de música para o município de Florianópolis", Palestra. http://www.ceart.udesc.br/Revista_Arte_Online/abemsul/artigo6.html. Retrieved: April 27, 2011.

Giráldez, Andrea (1998), "Educación musical desde una perspectiva multicultural: diversas aproximaciones", Revista Transcultural de Música, TRANS Iberia 1, November, 219-230.

Green, Lucy (1988), Music on deaf ears: musical meaning, ideology, education, Manchester, Manchester University Press.

(1999), "Ideology", in Horner, Bruce and Thomas Swiss (eds.) (1999): Key Terms in Popular Music and Culture, Oxford, Blackwell Publishers, 5-17.

(2003a), "Why 'Ideology' is Still Relevant for Critical Thinking in Music Education", Action, Criticism, and Theory for Music Education, 2 (2), 2-20.

(2003b), "Music Education, Cultural Capital, and Social Group Identity", in Martin Clayton, Trevor Herbert and Richard Middleton (eds.) The Cultural Study of Music: a critical introduction, London Routledge, 263-273.

(2005), Meaning, autonomy and authenticity in the music classroom. Professorial Lecture, Institute of Education, University of London.

(2008), Music, Informal Learning and the School: A New Classroom Pedagogy, Aldershot, Ashgate.

Ibarretxe Txakartegi, Gotzon and Maravillas Díaz Gómez (2008), "Metaphors, intercultural perspective and music teacher training at the University of the Basque Country", International Journal of Music Education, 26 (4), 339-351.

Lemos, Maya Suemi (2010), "Música nas escolas: ações da Funarte em prol da implementação da Lei 11.769", Revista da ABEM, Porto Alegre, 24, 117-120.

Luedy, Eduardo (2009), "Analfabetos musicais, processos seletivos e a legitimação do conhecimento em música: pressupostos e implicações pedagógicas em duas instâncias discursivas da área de música", Revista da ABEM, Porto Alegre, 22, 49-55.

Mateiro, Teresa (2009), "Uma análise de projetos pedagógicos de licenciatura em música", Revista da ABEM, Porto Alegre, 22, 57-66.

Siankope, Joseph and Olga Villa (2004), Música e interculturalidad, Madrid, Ministerio de Educación y Ciencia, Los Libros de la Catarata.

Spain (2006), Education Act 2/2006, May 3, Official State Gazette, num. 106, Madrid, May 4, 2006, 17158.

\section{About the Authors}

Alberto Cabedo Mas

Department of Education, Universitat Jaume I, Castellón, Spain. 
ALBERTO CABEDO MAS, FLÁVIA MOTOYAMA NARITA

Flávia Motoyama Narita

Universidade de Brasília, Brazil (student at Institute of Education-University of London, UK). 



\section{JOÜRNALLOf THE ARTS II SOClETY}

\section{Editor}

Bill Cope, University of Illinois, Urbana-Champaign, USA.

\section{Editorial Advisory Board}

Caroline Archer, UK Type, Birmingham, UK.

Robyn Archer, Performer and Director, Paddington, Australia.

Mark Bauerlein, National Endowment for the Arts, Washington, D.C., USA.

Tressa Berman, California College of the Arts, San Francisco, USA;

UTS-Sydney, Australia.

Judy Chicago, Artist and Author, New Mexico, USA.

Nina Czegledy, University of Toronto, Toronto, Canada;

Concordia University, Montreal, Canada.

James Early, Smithsonian Institution, Washington, D.C., USA.

Mehdi Faridzadeh, International Society for Iranian Culture (ISIC), New York, USA, Tehran, Iran.

Jennifer Herd, Queensland College of Art, Griffith University, Brisbane, Australia.

Fred Ho, Composer and Writer, New York, USA.

Andrew Jakubowicz, University of Technology, Sydney, Australia.

Mary Kalantzis, University of Illinois, Urbana-Champaign, USA.

Gerald McMaster, Curator, Art Gallery of Ontario, Toronto, Canada.

Mario Minichiello, Birmingham Institute of Art and Design, Birmingham, UK.

Fred Myers, New York University, New York, USA.

Darcy Nicholas, Porirua City Council, Porirua, New Zealand.

Daniela Reimann, Karlsruhe Institute of Technology KIT, Institute of Vocational and General Education, Karlsruhe, Germany; University of Art and Industrial Design, Linz, Austria.

Arthur Sabatini, Arizona State University, Phoenix, USA.

Cima Sedigh, Sacred Heart University, Fairfield, USA.

Peter Sellars, World Arts and Culture, University of California, Los Angeles, USA.

Ella Shohat, New York University, New York, USA.

Judy Spokes, Arts Victoria, South Melbourne, Australia.

Tonel (Antonio Eligio Fernández), Artist and Art Critic, Havana, Cuba.

Marianne Wagner-Simon, World Art Organization, Berlin, Germany.

Please visit the Journal website at http://www.Arts-Journal.com for further information about the Journal or to subscribe. 


\section{The Arts in Society Community}

This knowledge community is brought together around a common shared interest in the role of the arts in society. The community interacts through an innovative, annual faceto-face conference, as well as year-round virtual relationships in a weblog, peer reviewed journal and book imprint - exploring the affordances of the new digital media. Members of this knowledge community include artists, academics, educators, administrators, advocates and policy makers, curators, researchers and research students.

\section{Conference}

Members of the Arts Community meet at the International Conference on the Arts in Society, held annually in different locations around the world in conjunction with global and local arts events.

The inaugural Conference was held in conjunction with the Edinburgh Festivals, Edinburgh, Scotland in 2006, and in 2007, in collaboration with the Documenta12, Kassel, Germany. In 2007 an International Symposium on the Arts was also held during the Armory Show in New York and in co-sponsorship with the Center for Art and Public Policy, Tisch School of the Arts, New York University. In 2008, the Conference was held at the Birmingham Institute of Art and Design, Birmingham City University, Birmingham, UK, with a special theme of Art and Communication. In 2009, the Conference was held at Venice, Italy in conjunction with the Venice Biennale. In 2010, the Conference was held at University of Sydney, Sydney College of the Arts, Australia. In 2011, the Conference was held at Berlin-Brandenburg Academy of Sciences and Humanities, Berlin, Germany. In 2012, the Conference will be held in Art and Design Academy, Liverpool John Moores University, Liverpool, UK.

Our community members and first time attendees come from all corners of the globe. The Conference is a site of critical reflection, both by leaders in the field and emerging artists and scholars. Those unable to attend the Conference may opt for virtual participation in which community members can submit a video and/or slide presentation with voice-over, or simply submit a paper for peer review and possible publication in the Journal.

Online presentations can be viewed on YouTube.

\section{Publishing}

The Arts Community enables members to publish through three media. First by participating in the Arts Conference, community members can enter a world of journal publication unlike the traditional academic publishing forums - a result of the responsive, non-hierarchical and constructive nature of the peer review process. The International Journal of the Arts in Society provides a framework for double-blind peer review, enabling authors to publish into an academic journal of the highest standard.

The second publication medium is through the book series The Arts in Society, publishing cutting edge books in print and electronic formats. Publication proposal and manuscript submissions are welcome.

The third major publishing medium is our news blog, constantly publishing short news updates from the Arts in Society Community, as well as major developments in the various disciplines of the arts. You can also join this conversation at Facebook and Twitter or subscribe to our email Newsletter. 


\section{Common Ground Publishing Journals}

\begin{tabular}{|c|c|}
\hline $\begin{array}{l}\text { AGING } \\
\text { Aging and Society: An Interdisciplinary Journal } \\
\text { Website: http://AgingAndSociety.com/journal/ }\end{array}$ & $\begin{array}{c}\text { ARTS } \\
\text { The International Journal of the Arts in Society. } \\
\text { Website: www.Arts-Journal.com }\end{array}$ \\
\hline $\begin{array}{l}\text { BOOK } \\
\text { The International Journal of the Book } \\
\text { Website: www.Book-Journal.com }\end{array}$ & $\begin{array}{c}\text { CLIMATE CHANGE } \\
\text { The International Journal of Climate Change: } \\
\text { Impacts and Responses } \\
\text { Website: www.Climate-Journal.com }\end{array}$ \\
\hline $\begin{array}{c}\text { CONSTRUCTED ENVIRONMENT } \\
\text { The International Journal of the } \\
\text { Constructed Environment } \\
\text { Website: www.ConstructedEnvironment.com/journal }\end{array}$ & $\begin{array}{c}\text { DESIGN } \\
\text { Design Principles and Practices: } \\
\text { An International Journal } \\
\text { Website: www.Design-Journal.com }\end{array}$ \\
\hline $\begin{array}{c}\text { DIVERSITY } \\
\text { The International Journal of Diversity in } \\
\text { Organizations, Communities and Nations } \\
\text { Website: www.Diversity-Journal.com }\end{array}$ & $\begin{array}{l}\text { FOOD } \\
\text { Food Studies: An Interdisciplinary Journal } \\
\text { Website: http://Food-Studies.com/journal/ }\end{array}$ \\
\hline $\begin{array}{c}\text { GLOBAL STUDIES } \\
\text { The Global Studies Journal } \\
\text { Website: www.GlobalStudiesJournal.com }\end{array}$ & $\begin{array}{c}\text { HEALTH } \\
\text { The International Journal of Health, } \\
\text { Wellness and Society } \\
\text { Website: www.HealthandSociety.com/journal }\end{array}$ \\
\hline $\begin{array}{c}\text { HUMANITIES } \\
\text { The International Journal of the Humanities } \\
\text { Website: www. Humanities-Journal.com }\end{array}$ & $\begin{array}{c}\text { IMAGE } \\
\text { The International Journal of the Image } \\
\text { Website: www.Onthelmage.com/journal }\end{array}$ \\
\hline $\begin{array}{l}\text { LEARNING } \\
\text { The International Journal of Learning. } \\
\text { Website: www.Learning-Journal.com }\end{array}$ & $\begin{array}{c}\text { MANAGEMENT } \\
\text { The International Journal of Knowledge, } \\
\text { Culture and Change Management. } \\
\text { Website: www.Management-Journal.com }\end{array}$ \\
\hline $\begin{array}{c}\text { MUSEUM } \\
\text { The International Journal of the Inclusive Museum } \\
\text { Website: www.Museum-Journal.com }\end{array}$ & $\begin{array}{c}\text { RELIGION AND SPIRITUALITY } \\
\text { The International Journal of Religion and } \\
\text { Spirituality in Society } \\
\text { Website: www.Religion-Journal.com }\end{array}$ \\
\hline $\begin{array}{c}\text { SCIENCE IN SOCIETY } \\
\text { The International Journal of Science in Society } \\
\text { Website: www.ScienceinSocietyJournal.com }\end{array}$ & $\begin{array}{c}\text { SOCIAL SCIENCES } \\
\text { The International Journal of Interdisciplinary } \\
\text { Social Sciences } \\
\text { Website: www.SocialSciences-Journal.com }\end{array}$ \\
\hline $\begin{array}{c}\text { SPACES AND FLOWS } \\
\text { Spaces and Flows: An International Journal of } \\
\text { Urban and ExtraUrban Studies } \\
\text { Website: www.SpacesJournal.com }\end{array}$ & $\begin{array}{c}\text { SPORT AND SOCIETY } \\
\text { The International Journal of Sport and Society } \\
\text { Website: www.sportandsociety.com/journal }\end{array}$ \\
\hline $\begin{array}{c}\text { SUSTAINABILITY } \\
\text { The International Journal of Environmental, Cultural, } \\
\text { Economic and Social Sustainability } \\
\text { Website: www.Sustainability-Journal.com }\end{array}$ & $\begin{array}{c}\text { TECHNOLOGY } \\
\text { The International Journal of Technology, } \\
\text { Knowledge and Society } \\
\text { Website: www.Technology-Journal.com }\end{array}$ \\
\hline $\begin{array}{c}\text { UBIQUITOUS LEARNING } \\
\text { Ubiquitous Learning: An International Journal } \\
\text { Website: www.ubi-learn.com/journal/ }\end{array}$ & $\begin{array}{l}\text { UNIVERSITIES } \\
\text { Journal of the World Universities Forum } \\
\text { Website: www.Universities-Journal.com }\end{array}$ \\
\hline
\end{tabular}

For subscription information please contact subscriptions@commongroundpublishing.com 